\title{
Different Lots of Implementation of R2P in Libya and Syria: From the Perspective of International Norms
}

Hanjing Yue*, Ying Zhu

Anhui University of Finance and Economics, Anhui, China

DOI: $10.36347 / \mathrm{sjebm} .2020 . \mathrm{v} 07 \mathrm{i} 11.001$

| Received: 30.10 .2020 | Accepted: 10.11.2020 | Published: 17.11.2020

*Corresponding author: Hanjing Yue

Abstract

Review Article

\begin{abstract}
Although the responsibility to protect is a new development of the theory of humanitarian intervention, its implementation still needs the authorization of the United Nations Security Council, so it has no legal effect and is only a moral obligation. Under the authorization of the Security Council, NATO implemented the responsibility to protect in Libya, but it eventually overthrew the Gaddafi government, bringing regime change into the responsibility to protect and forming the so-called Libyan model. From the perspective of international norms, NATO's approach went beyond the mandate of the Security Council, seriously violated Libya's sovereignty, and ran counter to the concept that "the principle of sovereignty takes precedence over the principle of human rights" advocated by China and Russia. Moreover, NATO's regime change in Libya had advocated its value concept that "only Western democracy is the most effective guarantee of human rights". Therefore, when the United States, Europe and other countries tried to implement the responsibility to protect and copy the "Libyan model" in Syria, they were resolutely boycotted by China, Russia and other countries. The current situation of the struggle is that the priority of the principle of sovereignty has been maintained to a large extent, and the diplomatic discourse system and international discourse power of China, Russia and other countries have also been safeguarded.

Keywords: Responsibility to protect; Libya; Syria; sovereignty; human rights.

Copyright (C) 2020 The Author(s): This is an open-access article distributed under the terms of the Creative Commons Attribution 4.0 International License (CC BY-NC 4.0) which permits unrestricted use, distribution, and reproduction in any medium for non-commercial use provided the original author and source are credited.
\end{abstract}

\section{INTRODUCTION}

The responsibility to protect is a new development of the theory of humanitarian intervention, which makes a new interpretation of human rights and sovereignty, and provides a moral basis for western countries to push the UN Security Council to authorize humanitarian intervention. The practice of the responsibility to protect in Libya had been praised in the West. However, when they tried to implement the responsibility to protect in Syria and tried to copy the Libyan model, they were firmly opposed by China, Russia and other countries, so the implementation of the responsibility to protect in Syria was seriously hindered. The different lots of responsibility to protect in Libya and Syria are the result of intense game between international strategic forces. As for this kind of game, there are a lot of research results from geopolitics, but few from international norms. This paper will explore the reasons why responsibility to protect experiences different lots in Libya and Syria from the perspective of international norms.

\section{The Connotation and Essence of Responsibility to Protect}

The first normative obstacle to foreign intervention is the principle of sovereignty. Western countries should also strive to overcome this obstacle when they intervene in foreign countries. Their main way to break through this obstacle is to play the human rights card and concoct the so-called "humanitarian intervention" theory. The logic behind it is that "the sovereignty of a country cannot violate human rights. Sovereignty is national, human rights are stateless and belong to all mankind [1]". The protection of human rights is not only the responsibility of a government, but also the responsibility of the international community. If a government violates the human rights of its own people, the international community can protect its human rights beyond the sovereignty of the country.

Very few countries, such as the UK, still believe that the use of force to avert an overwhelming humanitarian catastrophe is a special and limited right of a country. This, of course, lacks broad support. It is generally accepted that humanitarian intervention without the Council's mandate under Chapters VII or 
VIII of the Charter of the United Nations lacks a legal and political basis. Indeed, Britain and others have been working unsuccessfully on the conditions under which the Security Council would authorize humanitarian intervention since shortly after the Kosovo war. As a result of concerns about the unilateralism inherent in the Kosovo operation and reflections on the 1994 Genocide in Rwanda, the international community has taken various other initiatives. The Canadian Government established the International Commission on Intervention and State Sovereignty, which submitted a report to Secretary-General Annan in December 2001 entitled the Responsibility to Protect. It contains two important innovations. The first is its proposal to shift the focus of the debate from the right to intervene to the responsibility to protect victims of serious human rights violations, a concept that includes prevention, response and post-conflict support. The second is its claim that sovereignty implies a state's responsibility to protect its citizens from human rights violations, and that when states are unable or unwilling to fulfil their sovereign responsibilities, "the international community has a responsibility to act on its behalf [2]".

In March 2003, more than a year after the publication of the report, the United States and its "voluntary alliance" invaded Iraq without the authorization of the Security Council. The reason was to prevent Iraq from deploying weapons of mass destruction and to respond to Saddam's atrocities against Iraqi Kurds and Shiites. But the US action caused controversy, was widely criticized around the world, and prompted UN Secretary General Kofi Annan to set up the High-Level Panel on Threats, Challenges and Change. The report of the High-level Panel in December 2004 and Annan's own report of April 2005, In Larger Freedom: Towards Development, Security and Human Rights for All [3], set out a series of criteria in similar terms as to when the Security Council should be prepared to authorize humanitarian intervention. In this way, the United Nations established a global system to deal with the grave suffering of mankind and approved the concept of the responsibility to protect, which aims to address genocide, war crimes, crimes against humanity and ethnic cleansing. This concept consists of three pillars: 1. The responsibility of a State to protect its residents; 2. The responsibility of the international community to assist individual countries; 3 . If national protection fails, it is the responsibility of the international community to intervene (including military intervention) [4].

However, in the 2005 World Summit Outcome, the heads of state and government pointed out that "if peaceful means are not sufficient to solve the problem and the national authorities concerned are obviously unable to protect their people from genocide, war crimes, ethnic cleansing and crimes against humanity, we are ready to deal with them on a case by case basis through the Security Council in accordance with the Charter, including Chapter VII and, where appropriate, in cooperation with relevant regional organizations, to take collective action in a timely and decisive manner [5]". Importantly, both legally and politically, the 2005 World Summit Outcome confirmed that law enforcement actions to protect populations from genocide, war crimes, ethnic cleansing and crimes against humanity are within the purview of the Security Council. This shows that the consensus of the international community on humanitarian intervention is that humanitarian intervention authorized by the Security Council is legal; so-called humanitarian intervention carried out by individual countries or groups of countries without the authorization of the United Nations is illegal; even when practicing the responsibility to protect, it needs the authorization of the United Nations Security Council and should be dealt with "on a case-by-case basis". It is clear that the responsibility to protect still falls within the scope of collective security and does not promote new developments in international law, which "has evolved into a conceptual framework of discourse, which may be politically useful but has no legal effect [6]". Since the responsibility to protect is a moral obligation and political choice, not a legal right, there must be a separate legal basis before the State intervenes to fulfil this responsibility. For example, although the Secretary-General of the United Nations described Security Council resolution 1973 as confirming that the international community fulfilled its responsibility to protect in the event of Libya, it was the resolution itself, not any claimed legal grounds related to the responsibility to protect, provides a legal basis for action to protect civilians.

\section{The "Successful" Practice of R2P in Libya and Its Impact at the Level of International Norms \\ NATO's intervention in Libya is seen by}

Western countries as a model for the successful implementation of the responsibility to protect. It was mainly carried out through the following steps.

The first step was to provide evidence that the international community was needed to protect Libyan civilians. The above analysis has shown that the responsibility to protect theory is an attempt to make it easier for the United Nations Security Council to be persuaded to authorize humanitarian intervention. So in order to implement the responsibility to protect against Libya, one must first provide evidence that the international community was needed to protect Libyan civilians from a humanitarian disaster, or the fact that Libyan civilians were suffering from a humanitarian disaster while their government was unable to respond or that the government itself was the maker of the humanitarian disaster. Influenced by the political upheaval in Tunisia and Egypt, there were also activities to protest against Gaddafi's Government in Libya, which facilitated the presentation of relevant "facts". Violence broke out in Libya in mid-February 2011 when the Gaddafi regime tried to violently crack down on 
protesters. The conflict escalated and the rebels soon occupied Benghazi, opening the way for armed confrontation between the two sides. Normally, it is understandable for a government to use force against its own armed insurgents, but Western countries condemned it and supported the insurgents, thus further intensifying the political contradictions within Libya. In response to the rapidly deteriorating situation in Libya, the relevant United Nations agencies issued a series of condemnation statements, laying the foundation for subsequent intervention. On 22 February 2011, the under-Secretary-General for political affairs of the United Nations, Lynn Pascoe, briefed the Council in private consultations on the situation in Libya. A subsequent press release condemned the use of force by the Gaddafi government against "civilians" [7]. On 25 February 2011, the United Nations Human Rights Council adopted a resolution on Libya, condemning systematic human rights violations and calling on the Libyan Government to "fulfil its responsibility to protect the people". It was pointed out that government violations may constitute crimes against humanity. The resolution called for the establishment of the International Commission of Enquiry on Libya [8].

The second step was to push the UN Security Council to adopt a resolution imposing sanctions on the Libyan government and submitting the situation in Libya to the International Criminal Court for investigation. When Libyan leader Gaddafi did not stop acting against the rebels and their supporters, the Security Council unanimously adopted resolution 1970 on February 26, 2011. The text of the draft resolution was submitted by Bosnia and Herzegovina, Colombia, France, Gabon, Germany, Lebanon, Nigeria, Portugal, South Africa, the United Kingdom and the United States. The other four countries (China, Russia, India and Brazil) did not participate in the submission [9]. The resolution "condemned violence and the use of force against civilians", stated that attacks on civilians "may constitute crimes against humanity" and "recalled the responsibility of the Libyan authorities to protect their people. The resolution called for an end to human rights violations and various forms of sanctions, including an arms embargo, a travel ban and an asset freeze, against the Gaddafi regime and selected individuals among them. The resolution also referred the situation in Libya to the International Criminal Court for investigation and said the Security Council would take stronger measures if the Libyan authorities did not comply [10].

The third step is to urge the UN Security Council to adopt a resolution to establish a no-fly zone over Libya and take all necessary measures to protect civilians. In early March 2011, when Libyan government forces advanced towards the rebel stronghold of Benghazi, the situation further deteriorated. President Gaddafi threatened severe retaliation against rebels in the city. On 17 March 2011, the Security Council adopted resolution 1973 (draft resolution submitted by
France, Lebanon, the United Kingdom and the United States). Five countries, including permanent members Russia and China (the other three are Brazil, India and Germany) abstained [11]. The resolution, invoking Chapter VII of the Charter of the United Nations, authorized "all necessary measures" (excluding foreign military occupation of Libya) to protect Libyan civilians, enforce the arms embargo, impose a no-fly zone and strengthen the sanctions regime, and set up a panel of experts [12]. Although many countries, particularly Russia and China, opposed the use of force in Libya, the Arab League called to the Security Council to establish a no-fly zone over Libya, causing these countries to abstain from voting on the resolution so that it could be adopted.

In the fourth step, NATO took the initiative to carry out the task of "protection" and help the opposition overthrow the Gaddafi regime. Shortly after the adoption of Security Council resolution 1973, on March 24, NATO assumed responsibility for enforcing the arms embargo and no-fly zone and for protecting civilians a few days later. At the same time, NATO carried out extensive air strikes against Libyan government forces and facilities. Some of the attacks appear to be aimed at Gaddafi himself. With the support of such close air strikes, Libyan rebels acquired large tracts of territory over the summer and eventually overthrew the Gaddafi regime in October 2011. NATO believes that in order to "protect" Libyan civilians, it is necessary to attack the Libyan government, and only by implementing "regime change" in Libya can the goal of "protection" be truly achieved.

The above analysis of the process of the international community's implementation of the responsibility to protect in Libya shows that it is Western countries, especially the United States, Britain and France, that actively promote the implementation of this responsibility for protection, and the mode of implementation is as follows: the first step is to give evidence that civilians in the countries concerned need international protection (with the help of the United Nations Human Rights Council and regional international organizations, etc.). The second step is to promote the adoption of UN Security Council resolutions condemning and sanctioning the governments concerned and calling for the situation in the country to be referred to the International Criminal Court for investigation (in fact, an attempt to convict the country's leaders); the third step is to promote UN Security Council resolutions to "protect" civilians through military intervention in the countries concerned (establishing a no-fly zone). The fourth step is for NATO to assume the responsibility to protect and overthrow the governments of the countries concerned in the name of "protection." 


\section{The Implementation of the Responsibility to Protect} in Syria Blocked

The successful implementation of the responsibility to protect in Libya reflected the victory of the idea of "human rights taking precedence over sovereignty", which had an impact on the diplomatic discourse system of China and Russia, thus undermining the international discourse power of China and Russia. To some extent, it was out of the maintenance of their own diplomatic discourse system and the power of international discourse that when Western countries tried to implement the responsibility to protect in Syria and copy the Libyan model, China, Russia and other countries firmly opposed it.

From the above discussion, we can see that the UN Security Council must be the most important stage for the debate over whether to implement the responsibility to protect on Syria. As a matter of fact, it is. Western countries have been trying to carry out humanitarian intervention in Syria based on the responsibility to protect. They have submitted draft resolutions at the United Nations several times in an attempt to carry out diplomatic isolation, political repression, economic sanctions, and even military strikes against the Syrian government in the name of humanitarianism, while at the same time supporting the
Syrian opposition and even de facto terrorists. In other words, they have been trying to imitate the pattern of intervention in Libya and impose a responsibility to protect against Syria and even the regime change by force. However, their attempts were unsuccessful in many cases because many of their draft resolutions were vetoed by Russia and China when they were submitted to the Security Council for a vote.

From the very beginning, western countries have been on the side of the Syrian opposition. No matter what they have done, even if it is a serious terrorist and violent act, such as the assassination of Syria's defense minister [13], they have strongly supported them, while they have denounced and threatened the Syrian government indiscriminately. From October 2011 to July 2012, western countries and other countries tried to adopt the draft resolution condemning the Syrian government's so-called serious human rights violations and imposing economic sanctions on it. Moreover, knowing that there were serious differences among the members of the Security Council and that the draft resolution could not be adopted, they still insisted on asking for a vote on the draft resolution in order to create public opinion pressure on the relevant parties. The main information of the relevant draft resolutions is shown in the following table [14]:

\begin{tabular}{|c|c|c|c|c|}
\hline Date & Draft & Agenda Item & Against & Abstentions \\
\hline $\begin{array}{l}4 \text { Oct. } \\
2011\end{array}$ & $\mathrm{~S} / 2011 / 612$ & $\begin{array}{l}\text { - Condemns use of force by Syrian authorities against } \\
\text { civilians } \\
\text { - Allow unhindered humanitarian access } \\
\text { - Inclusive Syrian-led political process } \\
\text { - Calls on states to exercise restraint in sale of arms to Syria } \\
\text { - Considers options under Article } 41 \text { of the Charter } \\
\text { (Sanctions) }\end{array}$ & $\begin{array}{l}\text { Russia, } \\
\text { China }\end{array}$ & $\begin{array}{l}\text { Brazil, India, } \\
\text { Lebanon, South } \\
\text { Africa }\end{array}$ \\
\hline $\begin{array}{l}4 \text { Feb. } \\
2012\end{array}$ & S/2012/77 & $\begin{array}{l}\text { - Condemns violence against civilians carried out by Syrian } \\
\text { authorities } \\
\text { - Supports League of Arab States' decision to facilitate } \\
\text { Syrian-led political transition } \\
\text { - Calls upon Syrian authorities to allow safe and unhindered } \\
\text { access for humanitarian assistance }\end{array}$ & $\begin{array}{l}\text { Russia, } \\
\text { China }\end{array}$ & none \\
\hline $\begin{array}{l}19 \text { July } \\
2012\end{array}$ & $\mathrm{~S} / 2012 / 538$ & $\begin{array}{l}\text { - Renewal of UNSMIS under Chapter VII } \\
\text { - Condemns violations of human rights by Syrian authorities } \\
\text { - All parties commit to cessation of hostilities and } \\
\text { implementation of six-point plan }\end{array}$ & $\begin{array}{l}\text { Russia, } \\
\text { China }\end{array}$ & $\begin{array}{l}\text { Pakistan, South } \\
\text { Africa }\end{array}$ \\
\hline
\end{tabular}

After rejecting the draft resolution concerning Syria in the Security Council for the first time, Mr. Churkin, permanent representative of Russia to the United Nations, said in an explanatory statement: "The Council cannot consider Syria's situation separately from Libya's experience. The international community is alarmed by the statement that compliance with Security Council resolutions concerning Libya pursuant to NATO interpretation is a model for future actions undertaken by NATO to implement R2P. "Russia's representative showed its high vigilance over Western attempts to copy Libya's intervention model in Syria. In his explanatory statement, $\mathrm{Li}$ Baodong, permanent representative of China to the United Nations, said: "The international community should provide constructive assistance to promote the realization of the goals I have mentioned. At the same time, the sovereignty, independence and territorial integrity of Syria should be fully respected [15]". The representative of China clearly expressed his basic stand against interfering in Syria's internal affairs under the pretext of humanitarian crisis.

In explanatory statements following two vetoes in February 2012 and July (see table above), Russian 
representatives stated that the draft resolution distorted facts and was insufficiently impartial, "sent a biased signal to all parties in Syria", "sanctions threatened exclusively against Syrian Governments", which would only exacerbate Syrian armed conflicts, and "will pave the way for sanctions implementation and subsequent external military intervention in Syria's internal affairs". In two explanatory statements, the representative of China expressed similar positions arguing that the draft resolution "overemphasized pressure on the Syrian government", which contained unbalanced content and pressure only on one side. The Chinese representative believed that the draft should not "require dialogue to achieve predetermined results or impose any solution", and should not violate fundamental norms of international relations under the Charter of the United Nations such as sovereign equality and non-interference in other countries' internal affairs. [16] Given lessons learned from Libya, China and Russia have reason to worry that if they support the unrestricted humanitarian access proposed in the draft, it may open the way for a safe zone, a no fly zone and eventual military intervention.

As they have done on Libya, western countries have also used the United Nations Human Rights Council to serve its purpose of discrediting the Syrian government and providing a basis for humanitarian intervention. On April 29, 2011, the Human Rights Council adopted a resolution calling for an investigation mission to Syria. On 11 May of the same year, Syria withdrew its application to join the Human Rights Council. The full name of this mission is Independent International Commission of Inquiry on the Syrian Arab Republic, which works closely with the United Nations International Impartial Independent Mechanism on the Syrian Arab Republic established in the same year to investigate alleged violations by Syria of international human rights law [17].

As the Syrian conflict developed, on July 17th 2012, the International Committee of the Red Cross concluded that there had been an armed conflict in Syria. Violations of international law in Syria were so large that the Commission considered that there was sufficient evidence that victims of this conflict had suffered from numerous crimes constituting war crimes and crimes against humanity. [18] War crimes are serious violations of international humanitarian law. Crimes against humanity are acts of murder, torture and sexual violence. They are part of a widespread and systematic attack against civilians. This raises questions about accountability. These offences may be tried by the International Criminal Court. This was seen by the West as an opportunity to crack down on the Syrian government as it did with Libya.

However, since Syria is not a member of the Statute of the International Criminal Court, unless the situation in Syria is submitted to the ICC by the United
Nations Security Council, the ICC does not have jurisdiction. Accordingly, France drafted a draft resolution on May 22nd 2014 requesting the Council to submit the crimes committed by interested parties in Syria to the International Criminal Court. Despite 13 votes in support of the Council's vote, the draft resolution was rejected by Russia and China. As Mr. Churkin, then Russia's permanent representative to the United Nations, said in his explanatory statement: "The draft resolution rejected today shows attempts to exploit further political passions by using the International Criminal Court and lay a final foundation for eventual external military intervention..." One cannot ignore the fact that the last Security Council resolution 1970 (2011) referred to one case (Libya case) before the International Criminal Court did not help resolve crises but contributed to the flames of conflict. Wang Min, deputy representative of China's permanent representative to the United Nations, said in an explanatory statement: "China believes that any action seeking to prosecute perpetrators of serious violations by the International Criminal Court should be carried out on the basis of respect for principle of complementarity. China is not a party to the Rome Statute. China remains reserved for the Council's submission of specific national circumstances to the International Criminal Court. This is our principled position [19]".

\section{Normative Reasons for the Different Lots}

The Council has never before authorized military intervention in a functioning country with the explicit purpose of protecting civilians from their own governments. In 1992, the United Nations Security Council Resolution 781 authorized the establishment of a no-fly zone over Bosnia, but the sole purpose was to provide humanitarian assistance, not to protect civilians. In the same year, UN Security Council Resolution 794 authorized a unified task force to enter Somalia, but this was carried out in the absence of a central government in Mogadishu. In 2008, violence broke out after the elections in Kenya, and although the United Nations responded under the guidance of the principle of responsibility to protect, it did not authorize military intervention, but successfully mediated a power-sharing agreement. However, it was only in Libya that the relevant UN Security Council resolutions strengthened the arms embargo and assets freeze, imposed a flight ban and, most notably, authorized "all necessary measures" to enforce the no-fly zone. The clear aim was to "protect" civilians and civilian populated areas threatened by attacks [20].

However, NATO's regime change in Libya was beyond the authorization of UN Security Council Resolution 1973, which was a serious violation of Libyan sovereignty, and China, Russia and other countries could not but remain vigilant against NATO's actions and were more worried about international peace and security. This is because it will not only boost the morale of anti-government forces in various countries, 
but also facilitate countries like Britain, the United States to arbitrarily interfere in other countries' internal affairs and infringe on the sovereignty of other countries. This convenience is shown as follows: if countries such as the United States and Britain are dissatisfied with the regime of a country, they then support the anti-government forces in that country to carry out anti-government activities, including violence; once the government suppresses the anti-government forces, they use the responsibility to protect as an excuse to obtain the authority of the United Nations to intervene in the country and overthrow the government. In order to effectively oppose the practice of obtaining the Security Council's authorization to intervene militarily in a country under the pretext of the responsibility to protect and taking the opportunity to overthrow its government, China and Russia must adhere to the idea that "the principle of sovereignty takes precedence over the principle of human rights", oppose the concept that "the principle of human rights takes precedence over the principle of sovereignty" upheld by Western countries, and safeguard their own diplomatic discourse system and international discourse. In fact, the game between Western countries and China, Russia and other countries on whether to implement the responsibility to protect in Syria reflects the international normative issue of "which is more important, sovereignty or human rights".

It can be seen that the basic logic of Western countries' attempts to carry out humanitarian intervention in Syria based on the responsibility to protect through the United Nations Security Council is that "the principle of human rights takes precedence over the principle of sovereignty." On the other hand, China, Russia and other countries strive to prevent the implementation of the responsibility to protect in the Security Council, and their basic normative position is that "the principle of sovereignty takes precedence over the principle of human rights." Therefore, at the level of international norms, the struggle whether to implement the responsibility to protect against Syria is reflected in the question of "which comes first, the principle of sovereignty or the principle of human rights". Because China, Russia and other countries have learned the lesson on the Libya issue, adhered to the idea that "the principle of sovereignty takes precedence over the principle of human rights", and vetoed the draft resolution submitted by Western countries to the United Nations Security Council, therefore, the implementation of the responsibility to protect based on the value of "the principle of human rights takes precedence over the principle of sovereignty" has been hindered in Syria.

\section{ACKNOWLEDGEMENT}

This article is part of the research work for the program "Research on the International Normative Questions of the Game between Big Powers in the Syrian Crisis" (16BGJ068) financed by the Chinese National Office for Philosophy and Social Sciences.

\section{CONCLUSION}

The responsibility to protect provides an innovative interpretation of the concepts of human rights and sovereignty and their interrelationships, with the main purpose of making it easier for the United Nations Security Council to authorize humanitarian intervention. As advocates of responsibility to protect believe that western democracy is the most effective institutional guarantee of human rights, responsibility to protect can easily become an important means of western "pro-democratic intervention" and thus a tool for regime change in so-called non-democratic countries. The practice of the responsibility to protect in Libya is like this. According to its own interpretation of UN Security Council Resolution 1973, NATO launched the protection of human rights in Libya in the form of military intervention and overthrew the Gaddafi government. The reason was that the Libyan anti-government forces were democratic forces, and the dictatorship of the Gaddafi government was a great threat to human rights in Libya. Overthrowing the Gaddafi government was an integral part of protecting human rights in Libya.

A country's political development path should be decided by its own people. NATO's military regime change in Libya under the pretext of the responsibility to protect is a serious violation of the sovereignty principle and a manifestation of putting the principle of human rights above the principle of sovereignty. If China and Russia had allowed it to develop, the world would have certainly been less peaceful (e.g. Libya once again plunged into a civil war after Gaddafi government had been overthrown. This further indicates that "responsibility for protection" cannot ensure humanity real and long-term protection against mass atrocities), also will harm the interests of China and Russia, undermine their diplomatic discourse system, weaken their international discourse power. In view of this, when the United States and Europe tried to implement the responsibility to protect in Syria to copy the Libyan model, it was firmly opposed by China, Russia and other countries. They have repeatedly rejected the draft resolution on Syria proposed by the United States and Europe in the UN Security Council, successfully maintaining the priority of the principle of sovereignty. The struggle over whether to implement the responsibility to protect against Syria reflects the international normative question of which comes first the principle of sovereignty or the principle of human rights. From the perspective of international norms, the reason why the implementation of the responsibility to protect in Syria is blocked is that China, Russia and other countries have learned the lessons from the Libyan issue, and resolutely safeguarded the priority of the principle of sovereignty and their own international voice.

\section{REFERENCES}

1 张乃根著：《国际法原理》, 中国政法大学出版 社, 2002 年, 第 27 页。 
2 See The International Commission on Intervention and State Sovereignty, The Responsibility to Protect, The International Development Research Centre, December 2001, pp. XI-XIII.

3 《大自由: 实现人人共享的发展、安全和人权》, 秘书长报告, UN Doc. A/59/2005，2005 年 3 月 21 日。

4 Klodia Khajadourian et al., "Ten Legal Questions: The War in Syria Explained in the Framework of International Law", The Nuhanovic Foundation, May 2018, p.17.

5 《2005 年世界首脑会议成果》, 联合国大会第 60/1 号决议, UN Doc. A/RES/60/1，2005 年 10 月 24 日。

6 Michael P. Scharf, "Striking a Grotian Moment: How the Syria Airstrikes Changed International Law Relating to Humanitarian Intervention", Chicago Journal of International Law, Vol. 19, No. 2, Winter 2018, p. 17.

7 "Insights on Libya," 22 Feb 2011, https://www.whatsinblue.org/2011/02/insights-on-li bya.php\#.

8 Human Rights Council Res. S-15/2, U.N. Doc. A/HRC/S-15/2, February 25, 2011.

9 UNSC Meeting Record, 6491st Meeting, UN Doc. S/PV.6491, 26 February 2011.

10 See UNSC Res. 1970, UN Doc S/RES/1970 (2011), February 26, 2011.

11 UNSC Meeting Record, 6498th Meeting, UN Doc. S/PV.6498, 17 March 2011.

12 See UNSC Res. 1973, UN Doc S/RES/1973 (2011), 17 March 2011.

13 In July 2012, Syrian Defense Minister Rajha, Deputy Defense Minister Asef and former Defense Minister Hassan Tukmanni were killed in a rebel attack on a Syrian security building in Damascus. On November 6th, the same year, Mohamed, brother of Syrian parliamentary Speaker Al-Jihad, was assassinated in Damascus. 《叙利亚暗杀行动 不断 议长家人上班途中遭枪杀》, 中国新闻网 ，2011 年 11 月 7 日， https://world.huanqiu.com/article/9CaKrnJxEeo。

14 Jenna Russo, "The Politics of R2P and Inaction in Syria: U.S., Russian, and Chinese Responses", January 23, 2018, https://www.imemo.ru/files/File/ru/conf/2018/230 12018/Russo.pdf.

15 See UNSC Meeting Record, 6627th Meeting, UN Doc. S/PV.6627, 4 October 2011.

16 See UNSC Meeting Record, 6711st Meeting, UN Doc. S/PV.6711, 4 February 2012 ; UNSC Meeting Record, 6810th Meeting, UN Doc. S/PV.6810, 19 July 2012.

17 Alicia Sanders-Zakre, "What You Need to Know about Chemical Weapons Use in Syria", Updated March 14, 2019, https://www.armscontrol.org/blog/2018-09-23/wha t-you-need-know-about-chemical-weapons-use-syr ia.

18 Natasha Harrington, "International Legal Consequences of the Conflict in Syria", November 2014, https://www.ennonline.net/fex/48/legalconsequenc es.

19 See UNSC Meeting Record, 7180th Meeting, UN Doc. S/PV.7180, 22 May 2014.

20 See Nathalie Tocci1, "On Power and Norms: Libya, Syria, and the Responsibility to Protect," Transatlantic Academy Paper Series, No.2, April 2014, p.3. 